\title{
The Specific of the Concept of Truth in the Scripture
}

\author{
Iulian Faraoanu \\ University "Alexandru loan Cuza", Iasi \\ Str. Vascauteanu 6, 700462 lasi, Romania \\ E-mail address: faraoanu@yahoo.com
}

Keywords: truth, historical accuracy, Bible, Scripture, Dei Verbum, principles, Gospel.

\begin{abstract}
The theme of this work is represented by the truth's concept in the Bible. By means of the pages of the Sacred Scripture, God, Truth par excellence, conveys the truth on him and on his plan of salvation. The theme on the truth in the Bible has been debated starting from the age of Enlightenment. Even nowadays, people are trying to identify solutions to the sensitive issues of historical accuracy and truth. The following pages are aimed at presenting certain aspects on the theme represented by the truth in the Bible, as well as the solutions to find such truth. Following a series of general aspects, the indications in Dei Verbum, we focus on the example of truth as reflected in the Gospel. The work ends with conclusions and the presentation of the way to identify the truth God wants to convey to us.
\end{abstract}

\section{INTRODUCTION}

The problem of truth contained in the Scripture has been debated upon especially after the Enlightenment; prior to Enlightenment, the Bible was considered to contain the whole truth. The Bible could not fail or be untruthful, as it was inspired by God himself.

Nevertheless, the Bible contains some difficult passages. Certain fragments contain contradictions: the flood was 40 days in Genesis 7:17 and 150 days in Genesis 7:24. Moreover, there are historical inconsistencies: the kingdoms listed in the book of Daniel are not confirmed by historical documents; scientific inconsistencies: the sky would be a kind of semicircle supporting the waters (Genesis 1); ethical inconsistencies: the herem rule (the destruction of the enemies, see Joshua 11:14-15). Finally, there are mythological stories such as those of Genesis 2-3, resembling a legend: the description of the sin of the first people.

Considering these difficulties, we ask ourselves: is it true what the Scripture says? Do these texts contain the truth that God wants to convey?

\section{BIBLICAL TRUTH AND "INERRANCY"}

A first explanation should clarify the concept of truth. In the Greek and Roman world, truth was an abstract idea, connected to the essence of things. One is closer to the idea of truth when it leaves the sensory sphere. Truth is fulfilled when what was hidden is brought to light. This concept of truth is also transposed in history: truth is the reality of the facts described in an accurate and sincere manner [1].

However, in the Hebrew world, truth pertained to religion and was considered in terms of fidelity: truth is represented by the word of God which becomes true in the historical events. It implies an existential truth that includes the perspective of faith in God. Absolute truth belongs to God who will ensure that the Word is fulfilled, although if often happens only in the future.

For Christians, truth is expressed and fulfilled in Christ. Truth is mainly a person who renews everything and renders people free.

As for the truth in the Bible, a constant aspect of the Hebrew and Christian doctrine was the belief that Scripture cannot fail. Some statements in the New Testament confirm this: "the Scripture cannot be set aside" (John 10:35); "Scripture must be fulfilled" (Luke 24:44); "Not the smallest 
letter or stroke shall pass from the Law" (Matthew 5:18). Moreover, according to Philo, no fault could be found in the words of the Law.

The Fathers, as well, often forced to respond to heresies, were of the opinion that there is no fault in the Bible. Given that Scriptures refer to Christ, they are perfect and true in their entirety. According to Augustine, Scriptures "speak of Christ and teach love" [2]. Clement argued that the Scriptures are true writings [3]. St. Justin was convinced that there can be no contradiction between the various passages of Scriptures [4]. Finally, Irenaeus stated that Scriptures are perfect [5]. Both the Old and the New Testaments contain the truth on God and man.

It should also be stated that the Apologist Fathers of the time strove to defend the truth of the Bible with the same tools of the Greek philosophy.

In the beginning, in the Patristic Period, explaining the difficulties of the Bible was a simple thing to do. It was acknowledged that there is much mystery and one cannot understand everything. Alternatively, people tried to harmonize differences, as Augustine did in his opera "De Consensu Evangelistarum": Jesus' preach in Matthew 5 was delivered in the mountains, then here was the preach in the plain in Luke 6. The most common explanation was an allegorical interpretation of controversial fragments: there were no historical facts, but rather metaphors or symbols. Often, explanations were given to combat heresies or erroneous views (e.g., the differences between the Synoptic Gospels and John).

St. Augustine finds more motivations when one does not understand some difficult pericopes: it is the manuscript used to read from that is faulty, the translator did not render the original meaning, or the one who reads did not understand anything.

It is the same St. Augustine who offers a principle for approaching the Bible, which still applies: "(Lord) wanted to make Christians, not scientists" [6]. "The Holy Spirit speaking through the sacred authors did not want to teach man things that were of no use for their salvation" [7]. Meanwhile, Augustine states that one must not necessarily look for the original words of Jesus in the Bible, but rather for the author's intention.

Following Augustine, the Bible remained for a long time the book, which contains the truth of any kind: historical, philosophical, scientific, religious, etc.

According to St. Thomas Aquinas, the Bible contains all truth and those who argue that Scripture contains something false commit a huge error [8]. Biblical truth, necessary for salvation, was a logical truth, able to lead to supernatural knowledge. In fact, theology was based on the principles (true axioms) contained in the Bible.

After the 16th century, the Church prefers to adopt apologetic positions in an attempt to defend the truth of the Bible. A controversial aspect regarding biblical truth is represented by Galilei and his theory (the earth revolving around the sun), which would be contrary to the Bible (the sun would be the revolving one): "Sun, stand still!" (Joshua 10:12-14). In fact, the biblical text did not address a cosmology issue, but rather celebrated God's intervention to save his people. As stated by Galilei, in line with Augustine, the Holy Spirit, by means of the Bible, wanted to teach us useful things for salvation, to show us not how heavens work, but how one can go to heaven. At the same time, Galilei recognize that Scripture is infallible and is inspired by the Holy Spirit.

In the 18th century, the historical truth in the Bible was more and more questioned. Confronted with the evolution of science, in order to defend biblical truth, some theologians tried to harmonize the biblical elements with science. An example to this end is the biblical chronology, an attempt to ensure harmony between the days of creation and the history stages in evolution.

Rationalism which accompanied Enlightenment also influenced biblical studies, leading to an interpretation limited to the criteria specific to reason.

In this context, we arrive at the concept of "inerrancy", i.e., the absence of any fault in the Bible. Pope Leo XIII was the first to introduce this concept in his encyclical Providentissimus Deus (1893). The Holy Father wanted to answer those who argued that the Bible contained, on the one hand, true and revealed "religious statements" while, on the other hand, it also contained "profane statements" (historical, physical, etc.) that reflected the mentality of the period when they were written, and thus being neither revealed nor exempt from fault. 
Such vision was favored by Maurice d'Hulst's suggestion, which made a connection between the infallibility of the Pope and the inspiration of the biblical authors. The First Vatican Council had already stated that, when speaking "ex cathedra" on matters of faith and ethics, intending to define a dogma, the Pope enjoys infallibility. Similarly, stated d'Hulst, in matters of faith and ethics, inspiration would ensure "infallibility" (inerrancy) to the biblical text, but such inerrancy would be limited to such aspects. Consequently, d'Hulst stated that, if the Church was the one preserving and transmitting the revealed truth, and infallibility relates to "faith and ethics", the Bible - as the source of truth - limitedly enjoys inerrancy in such areas.

Although the theory has many positive aspects (biblical truth must be interpreted from religious perspective), there were two objections. First, the idea of an intellectualism conception on Revelation, man being transmitted only doctrines. Secondly, if inerrancy only relates to faith and ethics, then it is acknowledged that the Bible also contains many profane aspects subject to fault.

D'Hulst's ideas were initially rejected. Providentissimus Deus states as follows:

"Nonetheless, one cannot tolerate the manner of acting of those who think they overcome many difficulties, stating that inspiration only regards matters of faith and ethics, as - regarding the truth of the statements - they erroneously believe that one should not seek what God would say, but rather to elaborate on the purpose why things were said. In fact, all the books of the Scripture with all the relevant fragments were written under the inspiration of the Holy Spirit. Therefore, divine inspiration cannot be at fault, as it not only excludes any fault by itself but it excludes and rejects fault to the same extent that God, the highest Truth, is necessarily the author of no fault" [9].

The Papal document also clarifies the relationship with natural sciences, confirming that the Lord did not intend to teach things that were not connected to salvation, salvation being, in fact, the purpose of the Bible.

In 1921, Pope Benedict XV resumes the theme on the inerrancy of Scripture. His work, Spiritus Paraclitus, reasserts the same ideas suggested by Pope Leo XIII. In additions, it rejects the theory on historical appearances according to which sacred authors do not explain the objective historical reality, but rather facts as they are presented in folk tales (a type of relative truth). The encyclical affirms that the historical truth of Scripture is part of faith.

The encyclical Divino Afflante Spiritu (1943) proposes further study of literary types (and the relevant cultural and historical context) used by hagiographers to discern the truth of the Bible, especially in historical narratives.

\section{THE CONCEPT OF "TRUTH" AS USED IN THE BIBLE: DEI VERBUM}

At the beginning of the Second Vatican Council, some wanted to propose the concept on biblical inerrancy [10]. However, after intense discussions, in the "Dei Verbum", the Council Fathers turned a new page on biblical truth. The concept of truth was not presented only from the perspective of the Greek culture (or of the rational, idealistic, existentialist philosophical trends), but rather as biblical and religious truth.

Thus, the Dei Verbum Dogmatic Constitution no longer used the concept on inerrancy, symbol of the period when defending faith was the only objective. Apart from the fact that this word includes a double negation (in $=$ without + errare $=$ no error/fault, opposite of truth), it is also a word difficult to understand (a neologism), relating rather to wandering of the mind and not necessarily to books.

The Council gave up this word especially because it was particularly interested in truth, a positive reality with a salvation purpose (redemptive and liberating). Revelation and the Word of Scripture are realities related to salvation. Dei Verbum 11 uses the same concepts:

"Considering that the statements of the inspired authors or of the hagiographers should be regarded as stated by the Holy Spirit, the books of the Scripture must be 
considered to transmit (teach) with certainty, faithfully and with no fault, the truth that God wanted written in the sacred texts for our salvation. Therefore, "All Scripture is God-breathed and is useful for teaching, rebuking, correcting and training in righteousness, so that the servant of God may be thoroughly equipped for every good work» (2Timothy 3:16-17)" [11].

In summary, the text of the Council points out as follows:

There is no separation between truths not meant for our salvation and others meant for our salvation; there is not an exclusive reference to the truth on faith and ethics; truth refers to the entire truth of revelation.

The perspective used for the analysis of the statements in the Scripture is God's plan of salvation for man. The analysis of texts has one goal: to identify God's plan of salvation to the benefit of man.

Biblical statements can also be analyzed from philosophical, historical, and archaeological perspective; however, the Bible has something specific, has a purpose: to teach without fault the salvific truth, for our salvation. Bible truth is not neither philosophical nor historical or scientific, but salvific and inherent to salvation history. Therefore, it is closely connected to history and revelation.

Bible teaches and conveys truth with all certainty, honesty and with no fault. Biblical truth is intended to communicate something, to teach.

Finally, there is an emphasis on God's will to inspire and convey truth. God wanted to convey the salvific truth, and biblical books contain such truth faithfully and with no fault. It is, ultimately, God's truth which gives life, the living and effective Word of God.

\section{THE HISTORICAL TRUTH OF THE GOSPEL}

The aspect on the historical truth of the Gospel has been studied by generations of Christians. This is also due to the desire to reach the original words and deeds of Jesus. Up to the Second Vatican Council, the Church adopted an apologetic opinion, stating the integrity of the text of the Gospel, its literary authenticity and the theory of the author as eyewitness (apostle or disciple of an apostle). In the recent decades, the historical accuracy of the Gospel is considered in a different manner, this being also due to the results of Formgeschichte and Redaktionsgeschichte. Tradition and redaction influenced the authenticity of the Gospel.

With regard to the truth of the Gospel, we should consider that that these writings are closely linked to oral tradition, always subject to adjustments in the conveyance of the memories on Jesus.

Furthermore, one needs to consider the meaning of history, not necessarily the accurate and actual data. The Gospel does not represent history, but its significance.

Several criteria are necessary in order to identify the historical truth of the Gospel. First of all, truth should not be considered as authenticity of each particular element (accuracy of data or information), but globally, the historical accuracy of the image of Jesus presented by the evangelists. The historical value of the image of Jesus is not the aggregate of the historical words and facts attributed to him, but rather the overall image of his person.

Second, we must consider the incomplete oral tradition, which represented the source for the Gospel writers. Therefore, a complete and accurate historical reconstitution of the image of Jesus is not possible. In fact, the intent of the evangelists was not to write a biography of Jesus.

Third, one should take into account the popular character of the environment for transmission of the traditions on Jesus. The communities of disciples presented no interest in historiography or a desire to put together a historical chronicle. Furthermore, there have been decades of evolution and adjustment of traditions also based on the recipients.

Fourth, one needs to accept the use of the Gospel in church. In the liturgy, worship and catechesis, there was not a precise memorization and repetition. 
Finally, the purpose of the writing of the Gospel is essential. The Gospel is not a biography of the Savior or chronicles on his public ministry. The purpose of the writing of the Gospel is connected to faith and the proclamation of salvation.

However, if we are looking for historical elements in the Gospel, we can appeal to St. Augustine's intuition, as he distinguished between "ipsissima verba Jesu" ("ipsissima facta Jesu") and "ipsissima voluntas". "Ipsissima verba Jesu" may represent words in Aramaic: "Abba", "effata", "talita qum". Fidelity to Jesus does not necessarily relate to something specific to the actual world. From this perspective, historical stands for what is in line with Jesus' intent or will, which can be perceived in the message of the Gospel. Therefore, the focus falls on "ipsissima intentio Jesu." On the other hand, the very work of translation from the Aramaic (Hebrew) categories into the Greek ones was a type of interpretation of the data on Jesus.

O. Culmann [12] had stated that everything is secondary in the Gospel (i.e., it was not received by us directly, but through the community), but everything is authentic, is connected to the person and the work of Jesus. This should be the starting point: everything is authentic in the Gospel, in opposition to Bultmann's skeptical statements.

There are ultimately some criteria used to determine the authenticity or the historical accuracy of the Gospel [13]. Mainly it exist four criteria of authenticity: antiquity; multiple attestation; dissimilarity and consistency.

The first criterion is the discontinuity with or disapproval for Hebrew or proto-Christian traditions. The words and deeds in the Gospels are original insofar as they differ from the Hebrew practices (copying of the traditions of the time is excluded) or Christian (the creative influence of the Church is excluded). For example, discipleship established by Rabbi Jesus; sitting at the table with sinners are practices contrary to Jewish traditions. On the other hand, the salvific value of the death of Jesus in Mark 10:45 could be an influence from the Pauline theology.

This criterion remains partial, as one does not need to create an image of Jesus the revolutionary, in constant disagreement with Judaism or the early Church.

Jesus remains rooted in the Hebrew world and the Church continues his work. It would be useful to have a deeper knowledge of Jesus, of Judaism and of the early Church. Furthermore, would it not be preferable to look for the elements of continuity between the Pre-Easter and Post-Easter traditions?

A second criterion for authenticity is the antiquity of the words or deeds (traditions of the Hebrew world). However, Greek influence in Palestine was quite strong.

The third criterion is represented by the multiple certification of an element in multiple locations or sources (Mark, Q, Matthew, Luke, the Pauline traditions, St. John's traditions, etc.); the oldest of these are more credible.

A final criterion could be the compliance with the Palestinian world or with the person of Jesus (historical, geographical, linguistic elements), which would exclude the Greek influence. For example, the recommendation in Luke 14:12-14 may come directly from Jesus: paradoxical invitation, radicalism and concern for children.

In order to determine the authenticity of an evangelical fact, it is necessary to have several criteria converging in the same direction.

At the same time, one needs to consider the unique character and the originality of Christ, which cannot be encapsulated in the patterns of history.

Furthermore, it is necessary to adjust Jesus' message to the life of the community, a traditional community (the tradition about the death and rise of Jesus proclaimed in the spirit of communion), hierarchical and oriented towards evidence (based on the apostolic testimony). In this way, elements, which could be attributable to the community, are: the use of certain parables according to the expectations of the members of the community, different expressions for ethical norms (see Mark 10:11 and Matthew 5:31-37), the rules on mission (see Mark 6:8-11; Matthew 10:10).

Finally, it is necessary to consider the element of faith which sees in Christ the Messiah (PreEaster experience) and the Risen Son of God, creator of salvation and worthy of worship. The 
evangelists were concerned about the religious requirements, about how to understand the person and the work of Jesus, the relevance of resurrection, etc.

In conclusion, it is necessary to sustain the historical value of the Gospel, Jesus' image in relation to the purpose of such writings (faith and salvation) and the insertion of the same into living communities of faith. There were communities where tradition was transmitted in all faith and expressed with enthusiasm under the influence of the Holy Spirit [14].

\section{PRINCIPLES AND GUIDELINES FOR FINDING BIBLICAL TRUTH}

„Because God has spoken in Scripture through man, in human terms, in order to understand what God wanted to reveal, the interpreter of the Sacred Scripture needs to carefully analyze what the hagiographers really intended to communicate and what God wanted to reveal by their words." [15].

First, God's intention to reveal himself to man by means of the sacred writers and their texts is superior, it goes beyond what they were able to communicate by their words. As can be noticed in the text above, Dei Verbum uses the conjunction "and" to separate two intentions: "what the hagiographers really intended to communicate" and "what God wanted to reveal by their words;" hence, the requirement to discover God's intention.

In order to discover the intention of the sacred author, it is necessary to carefully study the literary genres. For example, the book of Jonah is an educational story; one must not necessarily look for historical elements (Nineveh was not such a big city, the action is not historical!) or for the explanations on the myth of the man swallowed by a whale. The Book of Jonah provides a universal perspective on salvation. So, exegetical methods have their relevance in establishing the meaning of the Bible texts. The literary style facilitates the identification of the intention and the message of the author. Then, we must consider the social, historical and cultural circumstances of the biblical writings.

Second, it is necessary to take into account the unity of the Holy Scripture, analogia Scripturae. The texts of the Old Testament are a preparation for the New Testament. There is a relation of mutual enlightenment and comprehension: "In Vetere Novum latet, et in Novo Vetus patet". There is an evolution in the biblical revelation: from the oldest texts (Old Testament) to the newest ones (New Testament). The absolute novelty was brought by Jesus Christ, the Word which becomes flesh (see Hebrews 1:1-2).

To conclude, in order to establish the truth we must consider the following aspects.

First, the basis for the biblical truth remains the divine origin of Scripture and the inspiration of the Holy Spirit.

Second, there is a close relationship between "biblical truth" and the biblical canon. As regards religious life, the canon was called "rule of truth", and this "character as norm" of the Word is based on the truth therein.

To this end, a biblical statement cannot be properly understood if not considered within the entire canon of sacred books. The Bible is not a collection of "true statements" on various topics: creation, freedom, slavery, sin, salvation, the last days, judgment, hell, heaven, etc. It would be more appropriate to refer to the truth of the biblical message in the context of the books of the Scripture, as it is only this context that can ensure consistency of truth. For example, the concept of eternal life must be analyzed starting with the statements in this respect in the Old Testament (Daniel, 2Maccabees, Wisdom) up to what the New Testament says about the last realities.

At theological level, there is an evolution as regards certain ideas, such as the doctrine of reward, the afterlife. As regards the ethical truths, too, we note transformation with respect to form. When referring to herem: first of all, this was a practice of the time; the killing of the enemies was seen as a sacrifice to the god who defeated the enemy; second, the killing of the enemies removed the danger of idolatry, and implicitly helped to ensure fidelity to YHWH; finally, this practice did not last, as the Canaanites stayed to live together with Jews (see Judges); the practice on total destruction will disappear during Saul's time. 
Third, the Bible does not focus on science or history. Elements relating to metaphysics, natural sciences, history, must be considered from religious perspective. For example, a fundamental statement is the one on God - the Creator, regardless of the manner used (theory of evolution). Although biblical truth can be verified with the help of archeology, historical sciences, literary criticism, the Bible does however contain a language on faith. What is important is the truth of Revelation lived in faith and obedience to God's will.

There is ultimately a historical truth in the Scripture. The Bible history presents events from the perspective of God's relationship with humanity. The events have a special meaning, as they are God's actions, with no actual element, and being focused on the mystery of salvation. In analyzing truth, one must also take into account the relationship between "exact history" and "true history" (relationship with human experience that generates history and renders a meaning to it). Furthermore, we should also consider how Jews present history, historiography not being an exact science, but an art. Moreover, biblical knowledge is not necessarily rational, but implies relationship and love.

In order to explain certain obscure pages presenting immoral facts, violence, we need to take into consideration that biblical revelation is deeply rooted in history. God does not cancel history, but is inserted in the cultural and moral context of those times [16].

There are also detailed criteria to discover the historical accuracy of the Bible. We provide a brief presentation below. As we mentioned, the first criterion is that of discontinuity with respect to the facts and events of the preceding or contemporary times.

A second criterion is that of continuity or consistency with the environment and the vital situation of the text or book.

A final criterion of historical accuracy is that of multiple documentation on a biblical fact, either from the canon or from documents other than the Bible.

Fourth, there is an important connection established between biblical truth and hermeneutics. The goal of hermeneutics is the identification of truth, specifically the establishment of the author's intention when writing a text in a given time. Furthermore, one needs to identify and understood God's intentions that go beyond those of the author of the sacred text. In order to discover the truth in the Bible, it is necessary to read and interpret the Bible in the same spirit in which it was written, - namely in the living tradition of the Church.

Finally, the concept of truth must be considered in its complexity. Together with some scholars, we can find three levels of truth in the Bible: a) historical truth, meaning compliance with the real facts; b) truth in relation to the ultimate meaning of life; c) divine truth related to God's mystery [17].

\section{CONCLUSIONS}

To conclude, we would like to present the four dimensions of biblical truth. First of all, the historical dimension of truth. God's Word becomes flesh in human history, as the Bible also contains aspects specific to historiography or to other sciences. However, such aspects are merely the outer level of the religious message for salvation.

Second, the transcendent dimension: through Bible, God communicates himself, expresses his person and his will [18].

Third, the eschatological dimension: the Bible describes a history oriented towards fulfilment. There is dynamism of development and tension for the fulfilment of divine truth. The Church progresses towards knowledge of and total communion with Truth.

Finally, the inner dimension: getting close to the Bible and to the truth in it must also be specific to the existential level. Biblical truth remains an existential one, to be known and loved. This salvific Christian truth refers to the fulfillment of God's promises through Jesus Christ. God is the Truth who has revealed himself in history, who spoke to people, and, at the fullness of time, became flesh in his Son. 


\section{References}

[1] F. Lambiasi, Bibbia, Piemme, Casale Monferrato, 1991, 68-69.

[2] Augustine, De catechizandis rudibus, 4,4,8, in Corpus Christianorum, Series Latina, Turnhout, Breplos 1969, 46,128.

[3] Clement of Rome, Epistula Ad Corinthios, in J.P. Migne (ed.), Patres Latini, Paris 1857, 68, 505-554.

[4] Iustin, Dialogo cum Triphone, in Ph. Bobichon (ed.), Justin Martyr, Dialogue avec Tryphon, édition critique, Academic Press, Fribourg 2003.

[5] Irinaeus, Adversus Haereses, in J.P. Migne (ed.), Patrologia Graeca, vol. VII, Paris, 1857.

[6] Augustine, De Actis cum Felice Manichaeo, 1,10, in J.P. Migne (ed.), Patres Latini, Paris, 1857, 42, 525 .

[7] Augustine, De Genesi ad litteram, 2,9, in J.P. Migne (ed.), Patres Latini 34, 270.

[8] Thomas Aquinas, Summa Theologiae, A. D. Sertillanges (ed.), Paris, 1925, II.II, q. 171, a.6.

[9] Leon XIII, Providentissiums Deus, in Acta Apostolicae Sedae, 26 (1893-94).

[10] V. Manucci, Bibbia come Parola di Dio, Queriniana, Brescia, 1992, 252-258.

[11] Second Vatican Council, Dei Verbum 11, in Acta Apostolicae Sedae, 56 (1964).

[12] O. Cullmann, Les récentes études sur la formation de la tradition évangelique, in Revue d'Histoire et de Philosophie Religieuses 5 (1925) 459-477. 582-594.

[13] G. Barbaglio - R. Fabris - B. Maggioni, I Vangeli, Cittadella, Assisi, 1975, 33-34.

[14] M. Laconi, Vangeli sinottici, Elle Di Ci, Leumann, 1994, 120-130.

[15] Second Vatican Council, Dei Verbum 12, in Acta Apostolicae Sedae, 56 (1964).

[16] Benedict XVI, Verbum Domini, Presa Buna, Iasi, 2010, no. 42.

[17] I. Faraoanu, Biblia cuvant divin si uman, Sapientia, Iasi, 2011.

[18] F. Lambiasi, Bibbia, 78-80. 